\title{
Software development outsourcing risk factors and severity level: An empirical investigation
}

\author{
Alawiyah Abd Wahab ${ }^{1 *}$, Jamaiah Yahaya ${ }^{2}$, Faudziah Ahmad ${ }^{1}$, Siti Farina Zakaria ${ }^{1}$, Abdul Razak Hamdan ${ }^{2}$, Az- \\ iz Deraman ${ }^{3}$
}

${ }^{1}$ School of Computing, Universiti Utara Malaysia

${ }^{2}$ Faculty of Information Science and Technology, Universiti Kebangsaan Malaysia

${ }^{3}$ School of Informatics and Applied Mathematics, Universiti Malaysia Terengganu

*Corresponding author E-mail: alawiyah@uum.edu.my

\begin{abstract}
Software development outsourcing has become an important business strategy both in the public and private sectors not only in Malaysia but also worldwide. This is because it has the potential of lowering the operation cost, improving the quality of service and gaining access to advanced technological expertise. Although outsourcing can be very beneficial, it entails risks that could cause significant loss if organizations fail to identify and manage them. This study aims to identify and assess the severity level of risk factors involved in an outsourced software development project from the practitioners' perspective. Therefore, a survey has been conducted with 132 practitioners from the public sectors in the selected states within the northern Peninsular Malaysia. The survey included the risk factors identified in a thorough literature review study. The total mean value indicated of six main risk factors, four main risk factors are very highly critical.
\end{abstract}

Keywords: Software Development Outsourcing; Risk Factors; Criticality Level; Empirical Study.

\section{Introduction}

Software development outsourcing continues to be a global business strategy both in the public and private sectors. According to the study conducted by HFS Research [1], the Information Technology (IT) outsourcing is expected to grow at a compounded annual growth rate (CAGR) of $2.2 \%$ through 2016 to the end of 2020. The same source also estimated the global IT outsourcing markets to be worth US $\$ 657$ billion by the end of 2016. In Malaysia, the global business services sector also known as the shared services and outsourcing industry is expected to have a $10 \%$ to $15 \%$ growth in the next five years [2].

There are many reasons organizations outsource their software development. The most prominent driver to software outsourcing found in literature was cost reduction [3]. Other reasons include increased process efficiency, risk sharing, focus on core competencies and access to technological capabilities [4]. Despite the strategic advantages and cost benefits of software outsourcing, there are significant risks involved if the decision to outsource is not properly considered. Thus, it is imperative for the decision makers to have access to knowledge about different types of outsourcing risks and their associated severity level to make an informed decision before committing to an outsourcing project.

This research aims to develop a risk decision support algorithm for system development outsource. The work focuses on the early stage of the system development outsourcing life cycle [5], which considers the risks related to outsource service provider. This paper reports the results of the first stage of the research, which includes identifying the outsourcing risk factors and assessing their levels of severity.
The paper is structured as follows. In the next section, a brief background of the area is presented. Section 3 presents the methodology employed in this study. In section 4 , the findings of the study are presented. The discussion is provided in the last section.

\section{Literature Review}

Outsourcing has been an important business practice in the past few decades, especially in Information Technology. However, in terms of the definition of 'outsourcing' due to various opinions and understanding, outsourcing has been expressed in many ways. In the next paragraph, a few several definitions are highlighted.

In general, outsourcing simply means obtaining work previously done by employees inside the companies from services outside the company [6]. With respect to outsourcing in IT, the term has been confined to product and services relating to information systems [7]. For example, in [8] described information system (IS) outsourcing as "the significant contribution of external suppliers in the physical and human resources associated with the entire or specific component of the IT infrastructure in the user organization". Similarly, information technology outsourcing is defined as "an act of transferring some or all of the IT related decision making rights, business processes, internal activities and services to external providers, who develop, manage, and administering these activities in accordance with the contractual agreement". Since our work involves outsourcing that focuses on vendor selection process, the definition by [9] is adopted as it is closer to the study context.

Though outsourcing now a common practice and has benefitted many organizations, the outsourcing practice to a third party unfortunately does involve with some risks. In general, risks are the 
possibility of getting in a state of danger, which can cause loss because of undesired outcome or any situation or event that can potentially has a negative impact on project management [10]. In IT outsourcing, risk has been defined as engaging a third party, or another group entity (intra-group outsourcing) to provide IT systems or related services in order to improve an institution's performance and risk management [11]. Risk management is a process whereby the objectives are "to identify, address and eliminate software risk items before they become either threats to successful software operation or a major source of expensive rework" [7].

Software development outsourcing may take place either onshore, nearshore or offshore. Onshore software development outsourcing refers to outsourcing contracts that take place between two or more organizations within the same country. The potential benefits offered by onshore outsourcing include the ability to work with geographically and culturally close vendors. Nearshore software outsourcing refers to outsourcing contracts between companies within the same region or continent [12]. For example, a Malaysian company may make an outsource contract with vendors from Singapore, Thailand or Indonesia. Offshore software outsourcing refers to "the practice of hiring an external organization to perform some or all business functions in a country other than the one where the product will be sold or consumed" [13]. Typically, the offshore software development outsourcing focused on vendors in low wages countries such as India, China so as to take advantage from the reduced labour cost. In this study, we sought the perspectives of IT managers from public sectors with the experience of working with onshore software development outsourcing.

\section{Methodology}

The research methodology is conducted in two phases: (a) identification of risk factors and (b) assessment of severity level.

In the first phase, the information regarding the risk factors in software development outsourcing was collected from various journal articles, conference proceedings and other published research works. The keywords employed to identify papers that adequately represent the topic included software development outsourcing, information technology outsourcing, global software development and offshore software development. In addition to searching using search engines, the authors also follow references of selected papers for additional papers.

The aim of the second phase is to conduct an empirical study to gather practitioners' perceptions toward outsourcing risk factors related to service provider that could affect outsourced software development project. A survey research method with closed format questionnaire was used to collect data. The questionnaire was developed based on the results of phase I. There were four parts of the questionnaire. Part I and part II were meant to gather information about respondents and their company's profile respectively. In part III, information regarding the risk management were gathered while in the last part, information about outsourcing risk factors was sought. The questionnaire used a seven-point Likert scale $(1=$ very low critical; $7=$ very high critical $)$ to elicit the criticality that each respondent placed on each risk factors identified.

A pilot study was conducted involving a small group of staff at a university in the northern part of Malaysia who are responsible for managing outsourced system development projects. The aims of the pilot study were to test the research protocols and to improve the questionnaire design. Based on the respondents' responses, necessary changes were made to the questionnaire.

The sample for this study was drawn from the public sector agencies. Information systems managers working at these agencies were chosen as the subjects of this study since they are the personnel responsible for managing outsourcing projects.

Data screening and descriptive analysis were carried out using the Statistical Package for the Social Sciences (SPSS) software. Mean scores and frequencies were used to analyze the data. Since the seven-point Likert scale was used, appropriate interval need to be established to represent the critical level. Thus, the interval for this study is calculated as follow: $(6 / 5)=1.2$. Table 1 shows the mean intervals with the associated criticality levels.

Table 1: Mean Intervals for Criticality Level

\begin{tabular}{|c|c|}
\hline Mean interval & Criticality level \\
\hline $1.00-2.19$ & Very low critical \\
\hline $2.20-3.39$ & Low critical \\
\hline $3.40-4.59$ & Medium critical \\
\hline $4.60-5.79$ & High critical \\
\hline $5.80-7.00$ & Very high critical \\
\hline
\end{tabular}

\section{Results and Discussion}

The results of the study are presented according to the phases of the methodology.

\subsection{Phase I results}

Table 2 shows the risk factor constructs with their associated number of measures that have been identified in the first phase. The identified risk factors were grouped into reasonable construct based on their possible relevance. For example, risk factors such as vendor's price offering, experience and expertise, financial stability, skilled workers, management commitment, knowledge about tools and management cycle were group into a reputation construct. The measures for system services, contract management, client-vendor relationship, vendor's knowledge and software quality are tabulated in Table 4, 5, 6, 7 and 8 respectively.

Table 2: Measures of Study Variables

\begin{tabular}{|c|c|}
\hline Constructs & Measures \\
\hline Reputation & 7 items \\
\hline System Services & 6 items \\
\hline Contract Management & 5 items \\
\hline Client-vendor Relationship & 7 items \\
\hline Vendor's Knowledge & 3 items \\
\hline Software Quality & 5 items \\
\hline
\end{tabular}

\subsection{Phase II results}

The survey was distributed by hand, email and social media to seven different government sectors located in the northern part of Peninsular Malaysia. Of 200 questionnaires distributed, 132 were completed and returned.

The mean scores calculated for each construct were mapped to the scale in Table 1 to determine the critical level [14]. Table 3 shows the mean scores for vendor reputation construct.

Table 3: Vendor Reputation

\begin{tabular}{|c|c|c|}
\hline Risk Factors & Mean Score & Critical Level \\
\hline Price & 7.0 & Very high \\
\hline Experience and expertise & 7.0 & Very high \\
\hline Financial stability & 7.0 & Very high \\
\hline Skilled workers & 6.69 & Very high \\
\hline Management commitment & 6.24 & Very high \\
\hline Knowledge about tools & 6.35 & Very high \\
\hline Management cycle & 6.32 & Very high \\
\hline
\end{tabular}

Based on Table 3, all items that measure vendor reputation are of very high critical. However, three risk factors i.e., price offering, experience and expertise, and financial stability received the highest mean score indicating the most critical factors that affect vendor's reputation. Vendor's reputation has been known to influence clients' perception toward their capability and service quality [15]. Their lack of experience and financial instability could affect their ability to fulfill the outsourcing contract [16]. Hence, they are usually perceived as riskier and unreliable by the clients [17].

Six items were used to measure the system services provided by vendor. The mean scores and their critical levels are tabulated in the Table 4. 
Table 4: Vendor System Services

\begin{tabular}{|c|c|c|}
\hline Risk Factors & Mean Score & Critical Level \\
\hline Technical and operational & 6.95 & Very high \\
\hline Project schedule & 6.51 & Very high \\
\hline Project planning & 6.46 & Very high \\
\hline Project budget & 6.17 & Very high \\
\hline Software development methodology & 6.24 & Very high \\
\hline Software development tools & 5.36 & High \\
\hline
\end{tabular}

According to Table 4, the mean score for all items except software development tools indicates that they are of very high critical. Most of these factors are associated with the perceived ability of the vendor to manage a software development project. If a project is not managed properly, there are possibilities of budget overrun and delays [18]. Thus, these factors are perceived as very high critical by the respondents of this study.

Table 5 provides the mean scores for the risk of contract management with vendor. Of five items that measure vendor contract management, only two are considered as very high critical. The contract agreement clause that specifies all client's needs and requirements including but not limited to the scope, cost, penalty for non-performance is critical to be negotiated to ensure successful outsourcing project [19].

Table 5: Contract Management

\begin{tabular}{|c|c|c|}
\hline Risk Factors & Mean Score & Critical Level \\
\hline Contract agreement clause & 6.08 & Very high \\
\hline Penalty for extreme performance & 5.95 & Very high \\
\hline Understanding level of services & 5.45 & High \\
\hline Contract management & 5.68 & High \\
\hline Imbalance contract & 5.66 & High \\
\hline
\end{tabular}

Table 6 and 7 present the mean scores for client-vendor relationship and vendor's knowledge respectively. Seven items were used to measure client-vendor relationship whereas only three items were used to measure vendor's knowledge construct.

Table 6: Client-vendor Relationship

\begin{tabular}{|c|c|c|}
\hline Risk Factors & Mean Score & Critical Level \\
\hline Conflict or confusion & 5.99 & Very high \\
\hline Commitment & 6.76 & Very high \\
\hline Influence and power & 5.93 & Very high \\
\hline Teamwork & 6.02 & Very high \\
\hline Language barrier & 6.05 & Very high \\
\hline Trust & 5.48 & High \\
\hline Communication problem & 5.72 & High \\
\hline
\end{tabular}

According to Table 6, of seven items that measure client-vendor relationship, five are regarded as very highly critical. This result complements the findings of other researchers [20, 21] regarding the risk inherent in the client-vendor relationship. Understanding the client-vendor relationship not only critical before and during the contract phase but also continues after the contract ended [5]. This is to ensure that the relationship benefitted both parties.

Table 7: Vendor's Knowledge

\begin{tabular}{|c|c|c|}
\hline Risk Factors & Mean Score & Critical Level \\
\hline Advanced IT knowledge & 5.99 & Very high \\
\hline Domain knowledge & 6.76 & Very high \\
\hline Project management knowledge & 5.93 & Very high \\
\hline
\end{tabular}

The importance of vendor's technical and domain knowledge has been recognized in the literature. For example, the study of [22] on one long-term successful outsourcing project reveals that vendor's technical expertise contributed to the successful clientvendor relationship. In addition, the lack of knowledge on client's business know-how has been recorded as a risk factor in the previous studies $[18,23]$.

Table 8: Software Quality provided by Vendor

\begin{tabular}{|c|c|c|}
\hline Risk Factors & Mean Score & Critical Level \\
\hline Software testing & 5.78 & High \\
\hline Guideline & 5.12 & High \\
\hline Documentation & 5.79 & High \\
\hline $\begin{array}{c}\text { Compatibility of software and } \\
\text { hardware }\end{array}$ & 5.71 & High \\
\hline Version management & 4.84 & High \\
\hline
\end{tabular}

The last construct considered in this study is software quality risk factors. The mean scores for all items show that software quality is highly critical (Table 8). A close examination shows that software quality construct received a slightly lower mean score if we compare it with other risk factors. Since software quality risk factors are associated with software development in general, respondents of this study may feel that regardless of in-house development or outsourcing, software quality is still regarded as highly risky. However, in selecting a vendor, the respondents of this study may perceived other vendor qualities such as their reputation, system services offered and client-vendor relationship are more important.

\section{Conclusion}

The study reported here has identified six software developments outsourcing risk factors and assessed their severity levels. Of six constructs, four are considered very highly critical whereas the remaining two are considered highly critical. In this case, vendor reputation, system service, client-vendor relationship and vendor's knowledge are considered as very highly critical risk factors. Thus, it is important that project managers recognize these risks and plan appropriate mitigation strategies in order to avoid project failure. As for this study, our next step is to construct a risk decision support (RiDeS) algorithm for vendor selection in software development outsourcing based on the most influential risk factors identified in this paper.

\section{Acknowledgement}

This work was supported by the High Education Ministry under the Race Acculturation Collaborative Efforts (RACE) grant.

\section{References}

[1] P. Fersht, J. Snowdon and H. Santosh, The HFS Market Index - IT Services and BPO Market Size and Forecast 2016-2020. HFS Research, https://www.hfsresearch.com/market-analyses/emea-itservices-and-bpo-market-size-and-forecast-2016-2020 (2016)

[2] A. Sulhi, 2017 to be Promising and Disruptive for Global Business Services. http://www.theedgemarkets.com/article/2017-bepromising-and-disruptive-global-business-services-\%E2\%80\%94outsourcing-malaysia (2017).

[3] R. Gonzalex, J. Gasco, J. Llopis. Information systems outsourcing reasons and risks: A new assessment. Industrial Management and Data Systems, 110(2) (2010) 284-303.

[4] S.U. Khan, M. Niazi, R. Ahmad. Empirical investigation of success factors for offshore software development outsourcing vendors. IET Software, 6(1) (2012) 1-15.

[5] T.P. San and A. Abd Wahab. A systematic literature review on risk factors in software development outsourcing. Proceeding of the International Conference on ICT for Transformation 2016, Sabah, Malaysia. Azizah Ahmad (eds.), (2016) 154-158.

[6] G. Johnson, K. Scholes and R. Whittington. Exploring corporate strategy: Text and cases, Prentice Hall, Chicago (2008).

[7] B.W. Boehm. Software Risk Management: Principles and Practices. IEEE Software, 12 (1991) 32-41.

[8] L. Loh and N. Venkatraman. Determinants of information technology outsourcing: A cross-sectional analysis. Journal of Management Information Systems, 9(1) (1992) 7-24.

[9] S. Dhar and B. Balakhisnan. Risks, Benefits and Challenges in Global IT Outsourcing: Perspectives and Practices. Global Information Management, 14(3) (2006) 39-63.

[10] B.A. Aubert, M. Party and S. Rivard. Managing the risk of IT outsourcing. Proceedings of the 32nd Hawaii International Conference on System Science (1998).

[11] H. Hooman and R. Hassan. Classification and Analysis of Risks in Software Engineering. World Academy of Science Engineering and Technology, (2009) 446-452.

[12] O. Ishenko, Outsourcing of software development. Humboldt University of Berlin, Faculty of Economics, Berlin http://www.seoresearcher.com/research/Outsourcing-of-SoftwareDevelopment.pdf (2005) 
[13] T. Jelassi and S. Modwel. The sustainability of India's comparative advantage in IT offshore outsourcing. Proceedings of the Four teenth European Conference on information Systems (2006) 1-11.

[14] M.A. Afipudin, Risiko dan Struktur Pembahagian Risiko (SPR) Dalam Projek Pembinaan, Bachelor Thesis, Universiti Teknologi Malaysia, Johor, 2005.

[15] K.J. Park, Exploring the influence of vendor reputation in IT outsourcing decisions: A transaction cost perspective. Proceeding of the 45th Hawaii International Conference on System Sciences, 5002-5010 (2012).

[16] A. Aman and E.Z.E.A. Rahman. Managing relational risks in accounting outsourcing: Experiences of small firm. World Applied Sciences Journal, 15(1) (2011) 56-62.

[17] N. Zhang. An analysis framework of factors influencing China software and information service offshore outsourcing. IEEE Fifth International Conference on Information Technology, 875-880 (2008).

[18] R.T. Nakatsu and C.L. Iacovou, A comparative study of important risk factors involved in offshore and domestic outsourcing of software development projects: A two-panel Delphi study. Information and Management 46 (2009) 57-68.

[19] S.R. Syed Aris, A. Mohamed and N.H. Arshad, Preliminary study on risk management in e-government outsourcing projects. Proceedings of the 6th WSEAS International Conference on eactivities, (2007).

[20] J.H. Yahaya, N.F. Hamzah, and A. Deraman, Evaluating vendor's performance in outsource software development risks using analytic hierarchy process technique. Software Engineering Conference, 61-66 (2014).

[21] J.H. Yahaya, N.F. Hamzah, A. Deraman and Y.Y. Jusoh. Risiko pembangunan sistem secara penyumberluaran: Pengujian menggunakan teknik proses analisis berhirarki. Jurnal Technology (Science and Engineering), 72(1) (2015) 33-43.

[22] N. Levina and J.W. Ross. From the vendor's perspective: Exploring the value proposition in information technology outsourcing. MIS Quarterly, 27(3) (2003) 331-364.

[23] A.T. Chatfield and P. Wanninayaka, IT offshoring risks and governance capabilities. 41st Hawaii International Conference on System Sciences (2008). 